INDEPENDENT JOURNAL OF MANAGEMENT \& PRODUCTION (IJM\&P)

http://www.ijmp.jor.br

v. 11, n. 1, January-February 2020

ISSN: 2236-269X

DOI: 10.14807/ijmp.v11i1.1013

\title{
EFFECTIVE BOARD MANAGEMENT AND GOOD CORPORATE PERFORMANCE IN NIGERIAN PUBLIC LIABILITY COMPANIES
}

\author{
John Nkeobuna Nnah Ugoani \\ College of Management and Social Sciences, Rhema University, Nigeria \\ E-mail:drjohnugoani@yahoo.com
}

Submission: 2/28/2019

Revision: 3/19/2019

Accept: 5/2/2019

\section{ABSTRACT}

The need for effective board management and good corporate performance lies at the heart of good corporate governance theory because as the agency theory contends the managers' interest and the interest of shareholders are not almost always the same. Good corporate performance is the basis of the business as reflected through enhanced shareholder value measured by return on investment, return on assets or return on equity. Effective board management necessary for good corporate performance requires significant dose of emotional intelligence competencies such as integrity, transparency and loyalty. Such will ensure that the board of directors exercises internal control through effective monitoring roles aimed at protecting shareholders' interest as contemplated by the principles of good corporate governance. Ninety seven individuals participated in the study conducted through the exploratory research design. Data were analyzed through descriptive and regression statistical techniques and it was found that effective board management has significant positive correlation with good corporate performance. There is need for more understanding in this area, therefore further study could examine the relationship between corporate fraud and incessant bank failures in Nigeria despite various regulatory interventions. Consequent on the result of this study, it was suggested that the appointment of members of the board of directors of public liability companies in Nigeria must not be done without consideration to relevant experience.

Keywords: Effective board management, Good corporate performance, Emotional intelligence, Transformational leadership, Shareholder value 
ISSN: $2236-269 X$

DOI: 10.14807/ijmp.v11i1.1013

\section{INTRODUCTION}

Effective board management (EBM) requires that the chairman of the board of directors (BODs) should have the requisite knowledge, intelligence, experience, integrity, among other competencies necessary to offer effective board leadership. EBM provides the impetus for driving effective corporate governance practices for the major purpose of good corporate performance (GCP) in public liability companies (PLCs) everywhere, including Nigeria. GCP is often measured by enhanced shareholder value in terms of return on equity (ROE), return on investment (ROI), and return on assets (ROA).

GCP is equally a reflection of the quantum of turnover, productivity and profitability of the company driven essentially by the quality of board leadership through the mechanism of EBM. EBM is about board competence which provides the capacity for the effective management of the affairs of the company. No matter the nature of the corporate governance structure or the management structure of the company, EBM is the ultimate requirement to ensure compliance through best management practices.

Both the concepts of good corporate governance practice and good management practices suggest in a nutshell that the chairman or chief executive officer (CEO) of the company should have the capacity to comply with the basic principles of corporate governance for the efficient operation of the company. The different definitions about corporate governance try to emphasize that the board should be composed of good directors who have the critical competencies for the proper management of the company.

In which case, EBM would ensure that the long-term strategic goals of the company are well established to enhance the opportunities for the proper management and control of the company to produce the expected results. GCP lies at the heart of the whole idea of corporate governance and EBM, since the ultimate goal is that in proper application of the principles and practice, the company becomes more effective, efficient and simultaneously increases shareholder value and market value within the industry.

The principles of corporate governance provide the guidelines to ensure EBM for GCP. For example, the OECD (1999) principles of corporate governance state that they are meant for companies where shares are traded, but they could also apply to non-traded companies, like private companies and state owned enterprises (SOEs). The assumption here is that the focus is on PLCs, in which case, the BODs, of such enterprises have the responsibility to ensure the strategic guidance of the companies, involving the effective monitoring of management and 
DOI: 10.14807/ijmp.v11i1.1013

the boards accountability to the company and its shareholders, and to enhance the effective management of the company at all times.

EBM leads to good corporate governance which largely ensures that a proper management structure is constituted and put in place and ensures that the structure functions to maintain corporate integrity, reputation and responsibility of the company in relation to the interest of stakeholders and the public. GCP is best achieved through EBM rather than the traditional believe that board composition, or board size contributes to corporate performance of PLCs.

Whether the board size is small or large like 14 members and above or too small like below 5 members, so as to limit the inclusion of a wider expertise and competencies and abilities which are required for desired performance, it is important to promote EBM as the capstone for GCP. According to Gachoki and Rotich (2013) systems and structures can provide an environment conducive to good corporate governance practices but it is the acts or omissions of the people charged with relevant responsibilities that will determine whether governance objectives are actually obtained (NICHOLSON, et al, 2004; BHAGAT; BLACK, 2002; JENSEN; MECKLING, 1976; HERMALIN; WEISBACH, 1991).

The need for EBM and GCP corporate governance theory, because as the agency theory contends, the managers' interest and the interest of shareholders' are not almost always the same. For GCP in Nigeria, it is imperative for public quoted companies on the Nigerian Stock Exchange (NSE) to comply with institutional corporate governance policies or face sanctions.

According to Onyema (2014) the "corporate governance rating system introduced by the NSE is to promote integrity and transparency in listed companies which would form a natural and integral part of companies internal policies and mechanism" (HERMALIN; WEISBACH, 1991). EBM requires an effective board leader, and no business can be run successfully without an effective board. A board is required to start a business from day one, or even day zero.

Having a concept of the business is one thing, the next thing is how to set up a board and appoint managers to run the business, guided by the board. The chairman as the leader of the board should be somebody who must understand the nature of the business, and the people in the organization and having the capacity to harness all available resources to achieve what is in the best interests of the enterprise, the people and shareholders (ACHEBE, 2019).

\subsection{Statement of the Problem}


DOI: 10.14807/ijmp.v11i1.1013

Corporate boards without integrity can pose a great challenge to the performance of management and the company. Some corporate failures around the world expose a lack of transparency and accountability in the management of PLCs. A major case of board weakness in Nigeria can be seen in the 2006 Cadbury Nigeria PLC's accounting and auditing scandal that cost the global company over 15 million pound sterling and over 26 percent drop in share price.

Heavy losses in share prices of many PLCs in the recent decades relate to cases of board incompetence, fraud, weak and in-exemplary regulatory leadership. Like the case of the failed banks between 1990s and 2018, many of them were found to be in default of rendering statutory annual reports of many years, and the regulatory authorities watched helplessly.

At present the Securities and Exchange Commission (SEC) is said to be in default of producing its own annual reports for four (4) years and is being accused of double standards by significant others. These are among the serious challenges that can threaten EBM and GCP in Nigerian PLCs (SALAKO, 2018).

In the wake of the Nigerian financial crisis many banks collapsed due to board and leadership failures characterized by incompetence, corporate governance breaches, inadequate disclosure and lack of transparency about the financial position of banks. Also the capital market was infested by fraud and mismanagement that led to the crash of market capitalization from N13.0 trillion in 2008 to N4.3 trillion in 2009 (SANNI, 2010; OKORIE; UWALEKE, 2010; AYININUOLA, 2007; MING; LEE, 2014).

Even with the recent collapse of Skye Bank PLC due largely to board and management incompetence, there is evidence that other PLCs including banks are still having weak BODs. For example, according to Arogundade (2018) one of Nigeria’s leading banks, Diamond Bank PLC is no longer comfortable with the leadership of its Managing Director/Chief Executive Officer.

According to him, Diamond Bank PLC seems to be in dire need of new capital to fuel growth and profitability. He reports that the bank recently faced headwinds with profitability as it had challenges with its lending to the indigenous oil sector coupled with that, the bank lost some board members including the chairman who resigned in view of the unhealthy development in the board and management situation of the bank.

According to Ibrahim (2018) Forensic Investigation Reports (FIRs) show that the erstwhile management of the failed Skye Bank Plc contributed to its failure by engaging in 
DOI: 10.14807/ijmp.v11i1.1013

insider abuse, poor corporate governance and banking malpractices. The reports show other malpractices to include fraudulent false accounting, manipulation of accounting records to present false profits and ratios, unlawful loan and credit facilities, nondisclosure of directors' interests and lending beyond the single obligor limit.

He opines however, that the bridge bank resolution option of the Nigeria Deposit Insurance Corporation (NDIC) and the Central Bank of Nigeria (CBN) helped to save over 6,000 jobs and also resulted in depositors' unhindered access to their funds and the continuity of operations in 300 branches through Polaris Bank Ltd. For example, in the process of bank management, the role of the BODs, not only youthful exuberance matters, but also experience in the business of banking counts.

Diamond Bank that was once the choice of many Nigerians will be finally swallowed by Access Bank Plc by June 2019, for reasons not far from poor board leadership and management. The profit of the bank went down from N28.544b in 2013 to N25.4b in 2014. In 2015 the profit collapsed to a meagre N5.656b, and further down to a poultry N3.5b in 2016, and finally entered a loss position of N9.1b in 2017.

With about N200b NPLs and a liquidity ratio below 30\% minimum regulatory benchmarch, there is no doubt that the bank had reached the funeral level. Insider abuse is a major bank killer and a situation like this case where the GMD/CEO is also a supplier of services to the bank he s leading runs contrary to sound business ethics and the principles of good corporate governance and good management.

According to Alagbe (2018) you cannot compete with the man that will approve a contract for supply and maintenance services to the bank he leads, but this is bad management in the present century (SANUSI, 1995).

\subsection{Conceptual Framework of the Study}

A conceptual framework is a structure of the study idea or concept and how it is arranged and which summarizes the research problem in relation to relevant literature. It is often put in a schematic form that presents the principal variables and their hypothesized relationships. The conceptual framework of this study as shown in figure 1 was based on the model previously developed by Cavusgil and Zou (1994). 
DOI: 10.14807/ijmp.v11i1.1013

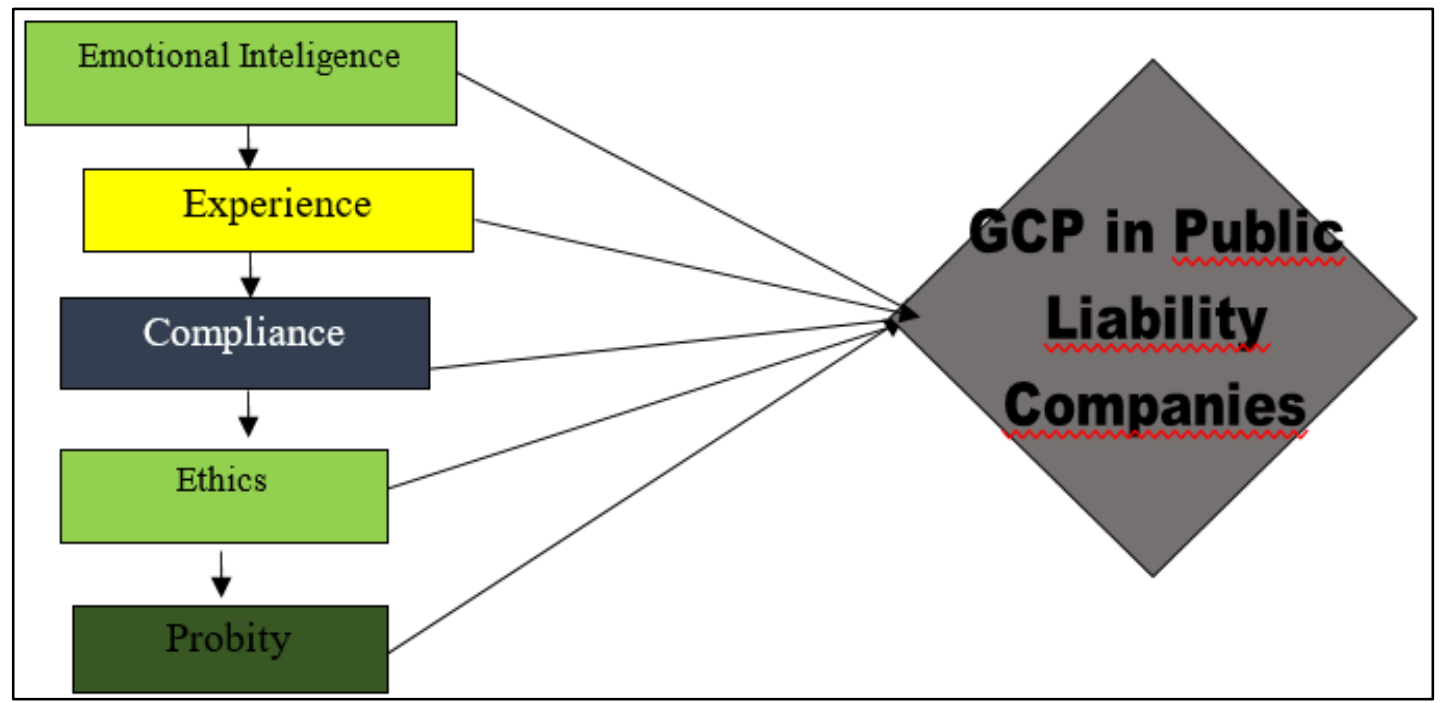

Figure 1: Effective Board Management and Good Corporate Performance Model EBM Source: Author Fieldwork (2019)

An effective board of directors (BODs) should be comprised of people with a high dose of emotional intelligence and experience that will enhance compliance, enforcement of ethical standards, transparency and probity of the board. Management performance is often measured by the amount of wealth management is able to create for shareholders.

The creation of such wealth reflects in GCP. EBM is imperative for GCP in Nigeria today to arrest the potentials of enterprise failures as witnessed in the last decades. This researcher is not aware of many studies in these areas at this time, when new rules are being put in place to restrict managing directors (MDs) from succeeding board chairmen so as to create EBM and GCP among PLCs in Nigeria.

According to Okwe (2018) it may soon become illegal for the managing director and chief executive officer of a publicly quoted company to succeed the chairman of the BODs except after a period of not less than three years of exiting the first position. Also under a proposed draft code, it may become unlawful for a person to hold concurrent appointments as chairman or executive director in more than one company, or for a managing director or an executive director to head committee in companies in which he is serving.

He explains that the code will promote ease of doing business, attract local and foreign investments and enhance the integrity of the Nigerian capital market by way of entrenching a culture of disclosure, transparency and accountability in the management of PLCs in Nigeria. The code will raise public awareness of good corporate governance in Nigeria. In view of the evolving scenario, it is expected that this work will provoke more studies by local researchers 
DOI: 10.14807/ijmp.v11i1.1013

in the areas aimed at finding a balance between EBM and GCP in PLCs in Nigeria (UGOANI, 2018; OPARANMA, 2010).

\subsection{Objective of the Study}

The study was designed to explore the relationship between EBM and GCP in Nigerian PLCs.

\subsection{Significance of the Study}

The study is expected to raise public awareness over the relevance of emotional intelligence, ethical codes, integrity, on EBM and GCP in Nigerian PLCs.

\subsection{Research Questions}

i. Does emotional intelligence influence EBM and GCP in organizations?

ii. Are you sure that experience has no relevance in EBM and GCP?

iii. Is compliance with regulatory framework critical for EBM and GCP?

iv. Do you believe that ethical codes are not important to enhance EBM?

v. Can probity by BODs enhance EBM and GCP?

\subsection{Hypothesis}

To meet the objective of the study the following hypothesis was formulated and tested at 0.05 level of significance.

- Ho: There is no relationship between EBM and GCP among PLCs in Nigeria.

- Hi: There is a relationship between EBM and GCP among PLCs in Nigeria.

\section{LITERATURE REVIEW}

Many factors can influence EBM and GCP among PLCs in Nigeria, including emotional intelligence and institulization of ethical standards. Emotional intelligence encompasses the competencies of self-regulation and integrity necessary for outstanding job performance, while ethical codes enhance the opportunities for the BODs of a company to do the right things in the interests of stakeholders.

A major task of Cadbury (1993) work on the financial aspects of corporate governance is to encourage self-regulation with the aim that would promote good management, shareholder value and ultimately increase market value for the interests of stakeholders. Nobody can seriously challenge the critical link between EBM and GCP because in Nigeria PLCs operate mainly pyramid structures and if members of the BODs lack emotional intelligence their action 
ISSN: 2236-269X

DOI: 10.14807/ijmp.v11i1.1013

may likely diminish the capability of minority shareholders to influence corporate policy and weaken the potentials for GCP.

Huge academic research reveals that effective corporate governance is closely related to effective management to reflect integrity, reputation, probity, transparency, accountability, and GCP. The concept of EBM connotes the need for optimum firm performance or GCP often reflected by profitability. In the last decades in Nigeria there have been low performances in PLCs due to weak board management influenced by weak compliance with ethical standards and weak regulatory oversight. Among the major cases was the notorious 2006 Cadbury Nigeria PLCs accounting and auditing scandal (OKARO; OKAFOR, 2013).

Partly because of the increase of business failures in Nigeria and elsewhere around the world there seems to be a refocus of attention and renewed calls for ethics, integrity, accountability and responsibility to ensure EBM and GCP among PLC in Nigeria (ADEBAYO, et al, 2013, BABATUNDE; OLANIRAN, 2009).

The corporate vision of any PLCs in Nigeria is always to remain in business with the aspiration to meet the expectations of the shareholders and customers. However, with the tragedy of relatively high levels of corporate failures in Nigeria, especially due to lack of observance of ethical codes, rules and regulations of doing business, there is a continuous search for effective and efficient board mechanisms to enhance GCP in PLCs in Nigeria (AFOLABI, 2015; AVRAM; AVASILCAI, 2014).

Many PLCs, mostly banks failed in the past decades largely due to the inability of the BODs to adequately regulate the remuneration of executive directors in tandem with good business ethics. However, to encourage GCP and to ensure that directors are fairly but responsibly, rewarded for their individual contributions, remuneration issues must be settled by negotiation and subject to the approval of a remuneration committee. Subsequently, reviews of base salary can be undertaken by reference to market movements, conditions and success as often measured by profitability and growth rates.

According to Greenbury (1995) decisions on base salary of directors are important not only in themselves but also because the level agreed is likely to be the platform on which so much else rests. It suggests that bonuses of directors should be expressed as a percentage of their base salary, share option may be allocated as a declared multiple of base pay and commonly, pension will be a proportion of final salary. This is critical to increase executive motivation and therefore business performance. 
DOI: 10.14807/ijmp.v11i1.1013

During the global financial crisis in 2008, it was brought into focus that the system of bonuses and remuneration of directors in financial institutions were unethical. It is argued that it encouraged excessive risk taking and irresponsible lending that led to the downfall of some of the world's biggest lenders and in turn the insurers insuring such risk.

\subsection{EBM and OECD Principles}

The OECD (1999) principles of good corporate governance stress on the need for EBM to enhance shareholder value. In essence, the principles emphasize that EBM is crucial for GCP, especially in the case of PLCs that often operate a pyramid structure of management. For example, Gachoki and Rotich (2013) suggest that incompetence, irresponsibility, lack of accountability, probity, transparency and mismanagement by the BODs are responsible for poor performance of state owned enterprises (SOEs) and other PLCs in Kenya.

Nicholson, et al, (2001) argue that diagnosing and understanding the dynamics of board effectiveness is a major focus of corporate governance and performance. EBM ensures internal control through BODs effective monitoring roles aimed at protecting shareholders' interests (ZAHRA; PEARCE, II, 1989).

It also enhances external cohesion through compliance with regulatory control mechanisms, and corporate reporting, disclosure and codes to enhance GCP. EBM also provides the necessary managerial behavior that makes it possible for the providers of corporate capital to be equitably rewarded.

The OECD (1999) principles of good corporate governance state that they are mainly for companies where shares are traded but that they could also apply to non-traded companies, like, private companies and SOEs. The implication of this basic assertion is that the focus is on PLCs in which case the BODs of such companies have the responsibility to ensure the strategic guidance of the company, the effective monitoring of management and ensuring the board's accountability to the shareholders.

Therefore, EBM would mean that the BODs must have the relative competence to passionately cultivate the culture of driving the affairs of the company to achieve its specific objectives. In this process, it must focus attention on ethics, corporate social responsibility (CSR), honesty, transparency and respect for employees. The goals of the enterprise must be in constant focus, there must be a sound organizational structure to show lines of responsibilities, communications and the type of management style and culture. 
DOI: 10.14807/ijmp.v11i1.1013

The concept of EBM also embraces the ideas of operational effectiveness, efficiency, probity, accountability and transparency in terms of financial reporting, disclosure requirements and compliance with statutory codes and regulations. The ability of the BODs to enhance EBM for GCP requires strong board leadership as well as the critical competencies embedded in the theory of emotional intelligence (EI).

\subsection{Building EBM Through EI}

EI is a form of intelligence that involves the ability to monitor one's own and others' feelings and emotions, to discriminate among them and to use such information to guide thinking and actions. It is a set of skills that underlie the accurate assessment, evaluation, expression, understanding and regulation of emotions.

Goleman (1998) argues that EI is a constellation of the qualities that identify high work performers. He suggests that emotional competencies are twice as important to people's success today as raw intelligence or technical know-how. He also argues that the further up the corporate ladder that a manager goes, the more important EI becomes for effective performance in the organization.

Therefore, EBM that is concerned with enhancing boardroom skills must take cognizance of the concept of EI. Goleman (1998) describes four (4) main competencies of EI that are relevant to superior management performance, as reflected in figure 2.

Emotional Intelligence

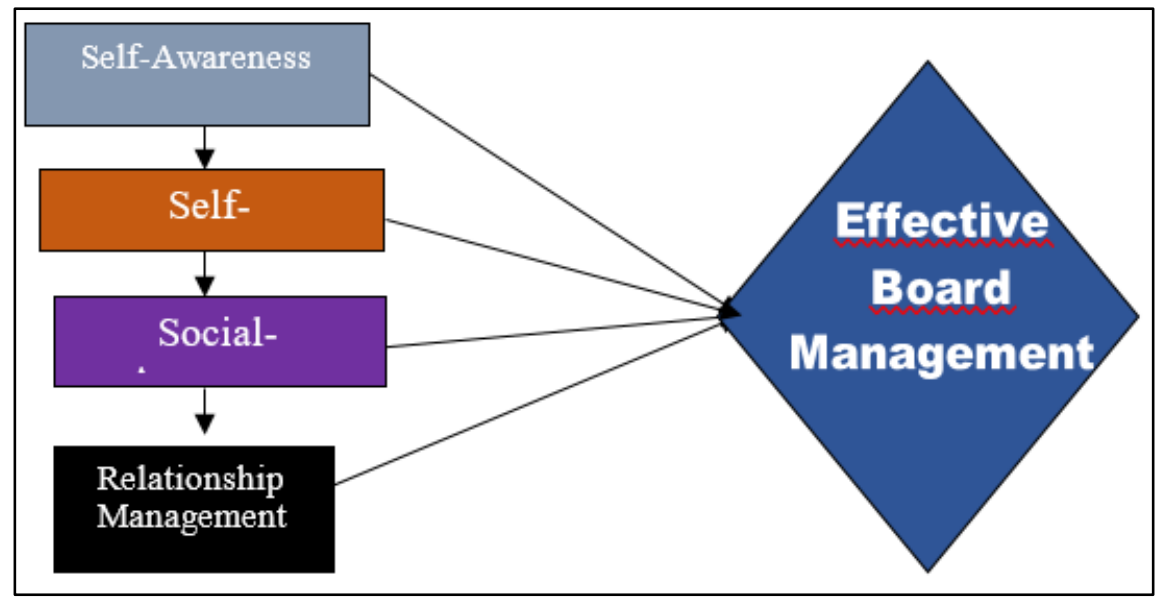

Figure 2: EI and EBM Model

Source: Author Fieldwork (2019)

According to Goleman (1998) EI competencies seem to operate most effectively in synergistic clusters, with the evidence suggesting that mastery of a critical mass or cluster of competencies is a necessary prelude to arouse the competencies in the other clusters, but when 
INDEPENDENT JOURNAL OF MANAGEMENT \& PRODUCTION (IJM\&P)

http://www.ijmp.jor.br

v. 11, n. 1, January-February 2020

ISSN: $2236-269 X$

DOI: 10.14807/ijmp.v11i1.1013

both are demonstrated the individual becomes typically more effective in professional and managerial positions.

The self-awareness cluster suggests the ability to recognize and understand one's moods, emotions, and drives as well as their effect on other people. This cluster is linked to three competencies: self-confidence, realistic self-assessment, and emotional self-awareness. The self-management cluster deals with the ability to control or redirect disruptive impulses and moods and to regulate one's own behavior together with a propensity to pursue goals with energy and persistence.

The six competencies associated with this component are: self control, trustworthiness and integrity, initiative and adaptability, comfort with ambiguity, openness to change and strong desire to achieve. The social-awareness cluster identifies the ability to understand the emotional make-up of other people; and skill in treating people according to their emotional reactions.

This is also linked to six competencies; empathy, expertise in building and retaining talent, organizational awareness, cross-cultural diversity, valuing diversity, and service to clients and customers. The last which is the relationship management cluster teaches about proficiency in managing relationships and building networks to get the desired result from others and reach personal goals, and the ability to find common ground and build rapport.

The five competencies associated with this component include: leadership, effectiveness in leading change, conflict management, influence, communication and expertise in building and leading teams, including resilience. Numerous academic researches' suggest that mastery of EI and the related competencies is the critical ingredient for effective performance (ARMSTRONG, 2004).

It is highly agreeable that EBM and GCP both require critical EI competencies. For example, the board chairman of a company requires superior leadership qualities to be effective in his position. Emotional competencies are based on a common underlying EI capacity that results in outstanding performance. Also, individual EI determines the potential for learning the practical skills that are based on its four main elements described in figure 2 and which are needed for workplace success.

In a typical boardroom situation, if board members are deficient in social awareness, for example, they will be inept at persuading or inspiring others at leading teams or catalyzing 
DOI: 10.14807/ijmp.v11i1.1013

change. Also, if they have little self awareness, they will be oblivious to their own weaknesses and lack the self-confidence that comes from certainty about their strengths.

For EBM, EI is capable of minimizing the incidence of non-compliance with laid-down internal controls and operational procedures, poor governance practices, disagreements between board and management, ineffective board oversight functions, inordinate MD/CEO ambition, like thinking of going on to succeed the chairman without a break, among other irregularities.

This is imperative because EI has won global recognition in general management and administrative perspectives, as the minimum benchmark for equity, equality, modesty, hardwork, focus, tenacity, love and spirituality, and performance. It is established from available academic and professional research that company directors with a high degree of EI are often motivated and willing to defer immediate benefits for long-term company success, and effective in promoting good governance of the corporate board.

According to Akpala (2011) good governance is the process by which the BODs, working through management, guide a company in fulfilling its corporate mission and safeguarding the company's assets. Fundamental to governance is the ability of individual directors to work in partnership so that they can balance long-term strategic and short-term operational responsibilities.

Also, good governance occurs when a board provides proper guidance to management regarding the strategic direction for the company and oversees management's efforts to move in that direction. Therefore, the interplay between board and management centres on managing the relationship between strategy and operation, both of which are very essential for corporate performance.

In the circumstance therefore, EI becomes invariably inescapable in EBM because while the BODs must be responsive for the interests of internal and external stakeholders, such as clients, employees, regulators and investors individual directors must be guided by the highest standards of ethical behavior, which is critical for protecting the trust the public places in the PLC.

According to Uzoka (2018) United Bank for Africa sustains steady growths in all key performance indices due to board and management resilience. For example, gross earnings rose from $\$ 333.9$ billion in 2017 to $\$ 374$.8billion in 2018, while before tax profit rose from $\$ 78.33$ 
ISSN: 2236-269X

DOI: 10.14807/ijmp.v11i1.1013

billion to 79.11 billion during the same period (NONGO, 2015; VISSANU; SARINTHREE, 2014).

\section{METHODOLOGY}

\subsection{Research Design}

The exploratory research design was adopted for the work. The exploratory design is historical in nature and does not often require a large sample nor a structured questionnaire. A combination of qualitative and quantitative techniques can be used in exploratory design (BRANNEN, 2005).

\subsection{Sources of Data}

Data were generated through primary and secondary sources. Secondary data are information that has been previously collected for some other purposes other than the research project at hand, while primary data are information gathered and assembled specifically for the research project at hand (AAKER, et al, 2004).

Each data collection method has advantages and disadvantages. However, the best approach is to use multiple methods of data collection because it affords the researcher a chance to cross-check the information obtained through the various methods (NELSON; QUICK, 2003).

\subsection{Sample Frame}

The sample frame comprised of the population in Nigeria interested in the topic under investigation (AAKER, et al, 2004).

\subsection{Sampling Technique}

Purposive sampling technique was used to select the sample for the study. This technique involves the selection of units based on factors other than random chance (ASIKA, 2004).

\subsection{Sample Size}

The sample size was determined through the sample ratio concept (Asika, 2004).

\subsection{Area of Study}

The study conducted in South-East Nigeria, comprised of five out of thirty six states in Nigeria and the Federal Capital Territory (FCT). Based on the $1 / 10^{\text {th }}$ principle, it is believed 
DOI: 10.14807/ijmp.v11i1.1013

that the opinion of the people in the zone is a good representative of the opinion of the people in Nigeria (Ezejelue, et al, 2008).

\subsection{Decision Rule}

The decision rule for the cut-off point for the analysis of responses to the research questions was at 3 points. This method is most appropriate to answer research questions (NWANKWO, 2011).

\subsection{Data Analysis}

Data were analyzed through descriptive and regression statistical methods and result presented in tables. Regression analysis is used to determine the level of relationship between the independent and dependent variables of study (NWORUH, 2004).

Ordinary Least Square (OLS) technique is a method used to estimate the unknown parameter in a linear regression model with the goal of minimizing the differences between observed variables in a dataset. The method was not chosen because of its simplicity but due to its unique properties of linearity, efficiency, sufficiency, least variances, unbiasedness and least mean errors (KOUTSOYAINNIS, 1977).

\subsection{Model Specification}

Model specification is the expression of a relationship into precise mathematical form. According to Koutsoyiannis (1977) economic theory does not indicate the functional form of any relationship. This means that economic theory does not state whether a relationship will be expressed in a linear form, quadratic form or in a cubic form. On the basis of this, the model specification for this analysis is:

$$
\mathrm{GCP}=\mathrm{b}_{0}+\mathrm{b}_{1} \mathrm{EI}_{\mathrm{t}}+\mathrm{b}_{2} \mathrm{Exp}_{\mathrm{t}}+\mathrm{b}_{3} \mathrm{Comt}+\mathrm{b}_{4} \mathrm{ETH}_{\mathrm{t}}+\mathrm{u}
$$

Where:

$\begin{array}{ll}\text { GCP } & =\text { Good Corporate Performance } \\ \text { EI } & =\text { Emotional Intelligence } \\ \text { EXP } & =\text { Experience } \\ \mathrm{COM} & =\text { Compliance } \\ \mathrm{ETH} & =\text { Ethics } \\ \text { bo } & =\text { Constant term }\end{array}$


ISSN: 2236-269X

DOI: 10.14807/ijmp.v11i1.1013

$\begin{array}{lll}\mathrm{t} & =\text { Time period } \\ \mathrm{u} & =\quad \text { Stochastic error term }\end{array}$

\section{PRESENTATION OF RESULT and explanations}

Table 1: Profile of Respondent $(n=97)$

\begin{tabular}{|c|c|c|c|c|}
\hline $\mathbf{S} / \mathbf{N}$ & Description & Category & Total & Percentage \\
\hline 1 & Gender & $\begin{array}{l}\text { a) Female } \\
\text { b) Male }\end{array}$ & $\begin{array}{l}35 \\
63 \\
\end{array}$ & $\begin{array}{l}36.08 \\
63.92\end{array}$ \\
\hline 2 & Education & $\begin{array}{l}\text { a) Diploma } \\
\text { b) Degrees } \\
\text { c) Others } \\
\end{array}$ & $\begin{array}{l}40 \\
32 \\
25 \\
\end{array}$ & $\begin{array}{l}41.24 \\
32.99 \\
25.77 \\
\end{array}$ \\
\hline 3 & Age & $\begin{array}{l}\text { a) } 18-35 \text { years } \\
\text { b) } 36 \text { - } 60 \text { years } \\
\text { c) } 61 \text { years } \& \text { above }\end{array}$ & $\begin{array}{l}45 \\
32 \\
20 \\
\end{array}$ & $\begin{array}{l}46.39 \\
32.99 \\
20.62 \\
\end{array}$ \\
\hline 4 & Experience & $\begin{array}{l}\text { a) Less than } 10 \text { years } \\
\text { b) } 11 \text { to } 20 \text { years } \\
\text { c) } 21 \text { years and above }\end{array}$ & $\begin{array}{l}28 \\
48 \\
21 \\
\end{array}$ & $\begin{array}{l}28.87 \\
49,48 \\
21.65 \\
\end{array}$ \\
\hline 5 & Class & $\begin{array}{l}\text { a) Low } \\
\text { b) Middle } \\
\text { c) High }\end{array}$ & $\begin{array}{l}23 \\
52 \\
22\end{array}$ & $\begin{array}{l}23.71 \\
53.61 \\
22.68\end{array}$ \\
\hline
\end{tabular}

Source: Author Fieldwork (2019)

Table 1 was used to illustrate that the respondents to the research statements were qualified and therefore competent to give reasonable answers to enhance the quality and potency of the study.

Table 2: Frequency and Mean for Responses to Research Questions.

\begin{tabular}{|c|c|c|c|c|c|c|c|c|c|c|}
\hline \multirow{3}{*}{$\mathbf{S} / \mathbf{N}$} & \multirow{3}{*}{ Restatements of research questions } & \multicolumn{5}{|c|}{ Scores } & \multirow{3}{*}{$\Sigma \mathbf{x}$} & \multirow{3}{*}{$\begin{array}{l}\text { No of } \\
\text { Resp. }\end{array}$} & \multirow{3}{*}{$\underline{x}$} & \multirow{3}{*}{$\begin{array}{l}\text { Decision } \\
@ \\
\text { points }\end{array}$} \\
\hline & & $\begin{array}{l}\mathrm{S} \\
\mathrm{A}\end{array}$ & A & $\mathbf{N}$ & $\mathbf{D}$ & $\begin{array}{l}\text { S } \\
\text { D }\end{array}$ & & & & \\
\hline & & 5 & 4 & 3 & 2 & 1 & & & & \\
\hline 1 & $\begin{array}{l}\text { Emotional intelligence does not make } \\
\text { positive impact on EBM and GCP }\end{array}$ & 10 & 20 & 2 & 10 & 55 & 211 & 97 & 2.18 & Rejected \\
\hline 2 & $\begin{array}{l}\text { Experience has no relevance on EBM and } \\
\text { GCP }\end{array}$ & 8 & 15 & 3 & 8 & 63 & 188 & 97 & 1.94 & Rejected \\
\hline 3 & $\begin{array}{l}\text { Compliance } 40^{\text {th }} \text { regulatory from work } \\
\text { enhances EBM and GCP }\end{array}$ & 40 & 30 & 2 & 10 & 15 & 361 & 97 & 3.72 & $\begin{array}{l}\text { Accepte } \\
\text { d }\end{array}$ \\
\hline 4 & $\begin{array}{l}\text { Ethical codes are not necessary to improve } \\
\text { GCP in PLCs }\end{array}$ & 7 & 10 & 4 & 6 & 70 & 169 & 97 & 1.74 & Rejected \\
\hline 5 & $\begin{array}{l}\text { Probity of the BODs can enhance EBM and } \\
\text { GCP in PLCs in Nigeria }\end{array}$ & 45 & 30 & 5 & 7 & 10 & 374 & 97 & 3.86 & $\begin{array}{l}\text { Accepte } \\
\text { d }\end{array}$ \\
\hline
\end{tabular}

Source: Author Fieldwork (2019)

The analysis in table 2 justified the potency of emotional intelligence and experience on EBM and GCP in PLCs. It also supports the widely held notion that probity of the BODs among others are critical for EBM and GCP. 
DOI: 10.14807/ijmp.v11i1.1013

Table 3: OLS Regression Analysis

\begin{tabular}{|l|l|l|l|l|}
\hline Variables & Coefficient & Std. Error & t-Statistic & Prob. \\
\hline C & 2628.283 & 2891.605 & 0.908936 & 0.3769 \\
\hline EI & 0.026165 & 1.611881 & 2.016232 & 0.0212 \\
\hline EXP & 88.64133 & 11.58477 & 7.651539 & 0.0000 \\
\hline COM & 3.209643 & 19.45605 & 0.164969 & 0.8710 \\
\hline ETH & -81.64971 & 67.73041 & -1.205510 & 0.2455 \\
\hline \hline R-Squared & 0.930882 & Mean dependent var. & & 25752.36 \\
\hline Adjusted R-Squared & 0.913602 & S.D. dependent var. & & 28417.35 \\
\hline S.E of regression & 8352.857 & Akaike info criterion & & 21.10285 \\
\hline Sum squared resid. & $1.12 \mathrm{E}+09$ & Schwarz criterion & & 21.35155 \\
\hline Log likelihood & -216.5799 & F-Statistic & & 53.87183 \\
\hline Durbin-watson Stat & 2.565410 & Prob (F-Statistic) 0 & & 0.000000 \\
\hline \hline
\end{tabular}

Source: Computation using E-Views Statistical Package, Version 3.1

The regression result showed the relationship between the independent variables and dependent variable. The goodness-of-fit result with $R^{2}=0.93$, and adjusted $R^{2}=0.91$ values are impressive. The implication is that about 93 percent of the systematic variations in the dependent variable are explained by the independent variables. This is the interest of the study.

\subsection{Discussion}

The $\mathrm{R}^{2}=0.93$ result of the regression analysis confirms that the independent variables of the study explain the dependent variable. The implication is that about 93 percent of the systematic variation in the dependent variable is explained by the independent variables. The goodness-of-fit test of the model is also splendid as the adjusted $\mathrm{R}^{2}$ is 0.91 .

The value D. W. is 0.25 that lie within the range between 1.5 and 2.5, so it can be stated that there is no autocorrelation among the independent variables of study. The analysis of the profile of respondents showed that they were competent to offer necessary information to enhance the quality of the study. The frequency and mean analysis provided credible evidence to support the regression result that overall, EBM has strong positive correlation with GCP.

This result supports the earlier finding of Zahra and Pearce, II, (1989) that an effective BODs has a strong relationship with good financial performance of a company. Also, Cherniss (2001) in a study of many organizations reports that emotional intelligence has positive relationship with organizational effectiveness, while Goleman (1998) equally opines that emotional intelligence of individual members in the workplace greatly enhances performance.

Ineffective supervision on the part of the BODs would invariably result in a lack of knowledge about the true position of the affairs of the company, lead to strategic myopia, complacency and poor performance. For example, at the heart of the banking system distress 
INDEPENDENT JOURNAL OF MANAGEMENT \& PRODUCTION (IJM\&P)

http://www.ijmp.jor.br

v. 11, n. 1, January-February 2020

ISSN: 2236-269X

DOI: 10.14807/ijmp.v11i1.1013

in the early 1990s, the regulators found out that most of the BODs of distressed banks in Nigeria were incompetent and ineffective.

To this extent, and to rekindle the integrity of the system the Central Bank of Nigeria had to sack the incompetent BODs and appointed Transitional Supervisory Boards (TSBs) to operate with adequate supervisory guidelines as regularly as they thought fit while rationalization and prudent management would be the watchword of the new management teams. At the end of their tenure some members of the TSBs who performed creditably retained their positions or were swapped, and those found incompetent were relieved of their positions (SANUSI, 1995).

A major reason for the election of the BODs by the shareholders of a PLC is the belief that a professional team can manage the business more effectively and more successfully than a roomful of shareholders, each with his own opinion could ever try to achieve. It is therefore expected that PLCs will grow and expand as the result of good management and operating efficiency based on EBM. Therefore EBM connotes the proper conduct, control, prudential and professional management of the company by the BODs to meet regulatory standards and laws to enhance shareholder value.

Companies that failed have been noted to have had about 60 percent weakness in their boards, including lack of a core sense of responsibility, transparency, accountability, as well as sound knowledge and experience in the broad area of management. Experience for instance, is an intrinsic affair that is ever required by directors for the core need of organizational performance. EBM requires transformational leadership and competency in the management function intrinsic to the business of the PLC. A PLC as a form of business organization which is authorized by law to act as a single person even though it may be owned by any number of persons, who are the shareholders, and are responsible for electing a BODs.

The BODs carries out policies and decisions of the shareholders and is responsible for reporting on the company's progress to the shareholders. It elects the officers or managers of the company, on whose skill the success of the company lies. In effect, therefore, the BODs once elected control the entire wealth of the company. If the BODs act with integrity, the shareholders value will increase, otherwise it will diminish or lead to losses and failure.

In order to enhance shareholder value, and the fact that the individual shareholders are willing to give up control over their funds in return for sharing in a business that is operated by highly skilled directors. In this regard, the BODs must demonstrate robust leadership and 
DOI: 10.14807/ijmp.v11i1.1013

relationship management skills in attempts to meet the expectations of shareholders who believe that their investment enables skilled management to direct the business on a larger, more efficient scale than would otherwise be possible and resulting in a share in the profits from skillful management.

With such bad cases like the widely publicized Enron's bankruptcy amid serious criminal charges against its accounting and auditing firm, the spotlight has shifted on the BODs on the need for probity to ensure accurate current and adequate financial reporting aimed at increased business support for its management, higher stock prices and greater ease for attracting and sustaining new capital.

EBM also implicates the need for the BODs to enforce the Securities and Exchange Commission's (SECs) guidelines requiring full disclosure of any information that would make a significant difference in the financial results of a PLC which could jeopardize GCP. Obviously for the purpose of EBM and GCP board governance rules anticipate that the performance of the board chairman should be evaluated annually or on any other basis recognized by the BODs, and the performance of the CEO should also be evaluated at least once a year by the chairman or a committee of the board for that purpose. EBM requires that the BODs must hold meetings at least once every three months and for the effectiveness of the board itself a committee of the board should carry out a review of the board to assess its mix of skills and experiences needed for GCP.

\subsection{Scope for further Study}

Further study should examine the relationship between corporate fraud and incessant bank failure in Nigeria. This is urgent because despite the worrisome bank failure episode of the 1990s through 2011, Skye Bank PLC recently failed against government assurances that the banking system is sanitized. It has therefore become necessary to find out new ways to cope with the challenge as the federal government has vowed to prosecute any director or member of the executive management that contributed to the failure of the bank (EGWUATU, 2018).

\subsection{Recommendations}

i. Integrity of individual directors will reflect in EBM and GCP. It is therefore necessary for shareholders to always ensure that persons without dubious character are elected into the BODs.

ii. During the Nigerian banking system crisis of the 1990s it was noted that most bank directors did not have the requisite experience in the broad area of management 
DOI: 10.14807/ijmp.v11i1.1013

to function effectively as directors. This contributed highly to the unprecedented number of failed banks during the period. It must therefore be born in mind that paper qualifications and physical appearance are not the most important elements to be considered in the election or appointment of directors by shareholders of PLCs in Nigeria.

iii. Audit committees in PLCs must be headed by a competent individual who has enough time to ensure that proper checks and balances take place to forestall discrepancies. The Cadbury Nigeria PLC financial manipulation went on for many years largely due to weak internal audit and control.

iv. The Managing director/chief executive officer of PLCs should not aspire to succeed the chairman without a break. This is important to ensure that a fresh hand comes on board with new ideas and also to mitigate the possibility of covering insider deals between former chairman and the new chairman that could impair the reputation of the company.

v. Directors must observe high ethical standards for EBM. Ethics as values and rules of conduct can help directors to develop essential skills such as discipline, honesty and loyalty in handling shareholders' funds put under their watch. Ethical standards will guide the BODs to appreciate what they are expected to apply to their work and where the boundaries of acceptable and unacceptable behavior lie.

\section{CONCLUSION}

EBM demands that the chairman of the BODs must be a transformational leader who has integrity and the requisite knowledge to lead the PLC on the paths of profitability and sustainability. A BODs composed by people who are emotionally intelligent are more likely than those without the competencies of loyalty, honesty and probity to achieve GCP.

EBM ensures internal control through BODs effective monitoring roles aimed at protecting shareholders interest. 97 persons participated in the study conducted through the exploratory research design. Data were analyzed through descriptive and regression statistical techniques and it was found that EBM has significant positive correlation with GCP. This result supports the findings of Zahra and Pearce, II, (1989), among others, that EBM is necessary for GCP. 
DOI: 10.14807/ijmp.v11i1.1013

\section{REFERENCES}

AAKER, D. A.; DAY S. S.; KUMAR, V. (2004) Marketing Research. $8^{\text {th }}$ edition. Boboken, N. J. John Wiley \& Sons.

ACHEBE, A. N. (2019) In The Boardroom With The Obi of Onitsha: 7 Habits of An Effective Board Leader. Saturday Sun, v. 16, n. 846, p. 48.

ADEBAYO, O. S.; AYENI, G. O.; OYEWOLE, F. A. (2013) Relationship Between Corporate Governance and Organizational Performance. International Journal of Business and Management Invention, v. 19, n. 19, p. 01-16.

AFOLABI, A. A. (2015) Examining Corporate Governance Practice in Nigeria and South African Firms. European Journal of Accounting, Auditing and Finance Research, v. 3, n. 1, p. 10-29.

AKPALA, P. E. (2011) Emotional Intelligence. In Microfinance Certification Programme: A Study Manual (Revised). Abuja, Chartered Institute of Bankers of Nigeria Press Limited.

ALAGBE, J. (2018) Merger, How Diamond Bank lost its sparkle Westafrica Business News, v. 5, n. 270, p. $1,4 \& 5$.

ARMSTRONG, M. (2004) Emotional Intelligence and Leadership Qualities. In ARMSTRONG, M. (ed.) A Handbook of Human Resource Management Practice. $9^{\text {th }}$ edition Kogan Page India, New Delhi: 588-589.

AROGUNDADE, F. (2018) Uzoma Dozie Under Pressure. Saturday Sun, v. 15, n. 826, p.29.

ASIKA, N. (2004) Research Methodology: A Practical Approach. Lagos. Mukugamu Brothers Enterprises.

AVRAM, E.; AVASILCAI, S. (2014) Business Performance Management in Relation to Corporate Social Responsibility, A Conceptual Model Development - Presidia- Social and Behavioural Science $1142-1146$

AYININUOLA, S. I. (2007) Leadership in Corporate Governance. Union Digest, v. 11, n. 172, p. 12-17.

BABATUNDE, M.; OLANIRAN, O. (2009) The Effects of Internal and External Mechanisms on Governance and Performance of Corporate Firms in Nigeria. Corporate Ownership and Control, v. 7, n. 2, p. 330-345.

BRANNEN, J. (2005) Mixing Methods. The Entery of Qualitative and Quantitive Approaches into the Research Process. International Journal of Social Research Methodology, v. 8, n. 3, p. 173-187.

CADBURY, A. (1993) The Cadbury Report on the Financial Aspects of Corporate Governance, UK.

CAVUSGIL, S. T.; ZOU, S. (1994) Marketing Strategy: Performance Relationship: An Investigation of the Empirical Link in Export Market Ventures: Journal of Marketing, n. 58, p. $1-21$.

CHERNISS, C. (2001) Emotional Intelligence and Organizational Effectiveness. In C. Cherniss and D. Goleman (eds) The Emotionally Intelligent Workplace. Jossey-Bass, San Francisco: p. 3-12. 
DOI: 10.14807/ijmp.v11i1.1013

EGWUATU, P. (2018) FG Vows to Prosecute Offenders in Failed Skye Bank. Saturday Vanguard, v. 17, n. 9234, P. 2.

EZEJElUE, A.; OGWO, E. O.; NKAMNEBE, A. (2008) Basic Principles in Managing Research Projects. $2^{\text {nd }}$ edition, Port Harcourt. Educational Books Ltd.

GACHOKI, S.; ROTICH, G. (2013) Influence of Corporate Governance on the Performance of Public Organization in Kenya (A case of Kenya Port Authority) Research Journal of Finance and Accounting, v. 4, n. 6, p. 205-215.

GOLEMAN, D. (1998) Working With Emotional Intelligence. USA, Bantam Book Publishing.

GOLEMAN, D.; BOYATZIS, R. E.; MCKEE, A. (2002) Primal Leadership: Realizing The Power of Emotional Intelligence. Boston, MA, Harvard Business School Press.

GREENBURY REPORT (1995) The 1995 Greenbury Report on Directors’ Remuneration, UK.

HERMALIN, B.; WEISBACH, M. (1991) The Effects of Board Composition and Direct Incentives on Firm Performance. Journal of Financial Management Perspectives, v. 10, n. 3, p. $35-77$.

IBRAHIM, U. (2018) NDIC, CBN Monitoring Probe of Failed Skye Bank Directors Ibrahim. Sunday Sun, v. 15, n. 4057, p. 36.

JENSEN, M.; MECKLING, W. (1976) Theory of the Firm: Managerial Behaviour, Agency Costs and Ownership Structure. Journal of Financial Economics, n. 3, p. 305-360.

KOUTSOYAINNIS, A. (1977) Theory of Econometric London, Macmillan Education Ltd. MING, O.; LEE, J. (2014) The Two Tier Board System and Underpricing of Initial Public Offerings: Evidence from Australia, Corporate Ownership and Control, v. 12, n. 1, p. $345-352$.

NELSON, D. L.; QUICK, J. C. (2003) Empirical Research Methodology. In D. L. Nelson and J. C. Quick (eds) Organizational Behaviour: Foundations, Realities, and Challenges. $4^{\text {th }}$ edition, USA. Thomson, South-Western.

NICHOLSON, R. GAVIN, J.; KIEL, H. (2004) A Framework for Diagnosing Board Effectiveness. Corporate Governance, v. 12, n. 4, p. 442 - 460.

NONGO, S. (2015) Effects of Leadership Style on Organizational Performance in Small and Medium Scale Enterprises (SMEs) in Nigeria. International Journal of Research in Management \& Business Studies.

NWANKWO, O. C. (2011) A Practical Guide To Research Writing, for Students of Research Enterprise (Revised Edition) Port Harcourt. Pam Unique Publishers Co. Ltd.

NWORUH, S. E. (2004) Basic Research Methodology for Researchers Trainees, and Trainers in Management Sciences. $2^{\text {nd }}$ edition Owerrri, Ambix Printers Nigeria.

OECD (1999) Principles of Corporate Governance, Paris.

OKARO, S. C.; OKAFOR, G. O. (2013) Drivers of Audit Failure in Nigeria - Evidence from Cadbury Nigeria PLC. Research Journal of Finance and Accounting, v. 4, n. 6, p. 14-17

OKORIE, G.; UWALEKE, U. J. (2010) An Overview of Financial Sector Reforms and Intermediation in Nigeria. Bullion, v. 34, n. 2, p. 19-29. 
DOI: 10.14807/ijmp.v11i1.1013

OKWE, M. (2018) New rule restricts MDs from succeeding board chairman. The Guardian, v. 35, n. 144601, p. 8.

ONYEMA, O. (2014) Listed Companies Must Comply With Corporate Governance Policies or be Sanctioned - NSE. Business Day, v. 12, n. 58, p. 15.

OPARANMA, A. O. (2010) The Organizational Culture and Corporate Performance in Nigeria. International Journal of African Studies, v. 3, n. 34-40.

SALAKO, T. (2018) SEC fails to file report for four years. The Nation, v. 13, n. 4390, p. 111

SANNI, H. T. (2010) Global Economic Crisis. The Need For African Government Interventions For Rapid Economic Recovery and Stability. Bullion, v. 34, n. 2, p. 9-18

SANUSI, J. O. (1995) Efficient Management of Distressed Enterprises of Banking \& Insurance Industry. Monthly Business \& Economic Report. First Bank of Nigeria, PLC Lagos: 2-13.

VISSANU, Z.; SARINTHREE, U. (2014) The Influence of Leadership Styles on Organizational Performance Mediated by Organizational Innovation: A Case Study of the Hospitality Industry in Thailand 2014 International Conference on Economics, Management and Development.

UGOANI, J. N. N. (2018) Good Corporate Governance and Organizational Performance in Nigeria. Amity Business Journal, v. 7, n. 1, p.1-10.

UZOKA, K. (2018) UBA Sustains Resilience as gross earnings hit N3756. The Nation, v. 13, n. 4462, p. 37.

ZAHRA, S.; PEARCE, II, J. A. (1989) Boards of Directors and Corporate Financial Performance: A Review and Integrative Model. Journal of Management, v. 15, n. 2, p. 291334. 